Island Studies Journal, Vol. 12, No. 1, 2017, 21-34

\title{
Island societies and mainland nation-building in the Mediterranean: Sardinia and Corsica in Italian, French, and Catalan nationalism
}

\author{
Marcel A. Farinelli \\ Independent scholar \\ marcelfarinelli@gmail.com
}

\begin{abstract}
In the history of Modern Europe, islands have generally been considered as passive spaces. Historically, however, Mediterranean island societies have played important-and often active-roles in the formation of nation-states and in nation-building processes. Little attention has been paid to the ways in which island societies have affected mainland nationalism. This article argues that Mediterranean islands offered rhetorical and symbolic elements that proved useful for the construction of mainland European national identities, largely because islandness, from a continental perspective, was seen as capable of conserving authenticity. This article draws upon the Mediterranean island case studies of Sardinia and Corsica and their relationships to Catalan nationalism, French nationalism, and Italian nationalism as well as wider nation-building processes.
\end{abstract}

Keywords: Catalan nationalism, Corsica, French nationalism, islands, Italian nationalism, nation-building, Mediterranean Studies, Sardinia

https://doi.org/10.24043/isj.3

(C) 2017 - Institute of Island Studies, University of Prince Edward Island, Canada.

\section{Introduction}

Sardinia, which is like nowhere. Sardinia, which has no history, no date, no race, no offering. Let it be Sardinia. They say neither Romans nor Phoenicians, Greeks nor Arabs ever subdued Sardinia. It lies outside; outside the circuit of the civilization. (Lawrence, 1999, p. 9)

This quotation by British novelist D.H. Lawrence reveals a common trope of islandness: the ahistorical dimension in which island societies are thought to exist. To be off-land is to lie outside common space. As noted by John R. Gillis (2004), islands in Western culture are places frozen in time, where utopias, myths, and fantasies could be located. They thus represent physical places suitable for metaphorical geographies, not for historical evolution. But this sense of lying outside history, as Lawrence wrote about Sardinia, is in contrast with the transformation that the Mediterranean experienced as a consequence of the French Revolution. During $19^{\text {th }}$ century, Mediterranean societies were slowly changing following industrialization and the formation of nation-states. It was as a result of the building of both nation and state that the actual map of Europe was defined. This process is quite well known for cases like France and Italy, but we know little about the role played by European islands of the Mediterranean, and even less about those in others seas.

Generally speaking, the connection between insularity and nationalism has been poorly investigated, except in the field of Island Studies. This specialized type of analysis has produced works that interpret islands as places where specific forms of governance can develop 
(Baldacchino, 2006; Depraetere \& Dahl, 2007; Hay, 2006; Khoo et al., 2015), or that propose a typology of island governance (Warrington \& Milne, 2007), while other scholars have focused their attention on the political and economic relationship between mainland and islands, analyzing the consequences that derive from it. This is a major aspect of island studies, a kind of approach that has produced significant studies, mainly in the field of political science (e.g., Grydehøj, 2016; Rodd, 2016; Veenendaal, 2015). Always from this point of view, some scholars have attempted to develop a theory of island nationalism, following the subnational island jurisdiction framework proposed by Baldacchino (2004, 2010; Baldacchino \& Hepburn, 2012; Fazi, 2009; Hepburn, 2012; Vezina, 2014), while European cartographical representation of islands has been suggested as a central element in the development of the nation-state model (Steinberg, 2005). But, there is a lack of historical analysis, and actually the only essay that, from the point of view of an historian, deals with the subject of nation-building and state-building in an insular context is a volume concerning the role of history-writing in the formation of a regional-insular identity in the Baltic Sea (Edquist \& Holmén, 2015).

\section{Figure 1: Corsica and Sardinia respect to Italy and France.}

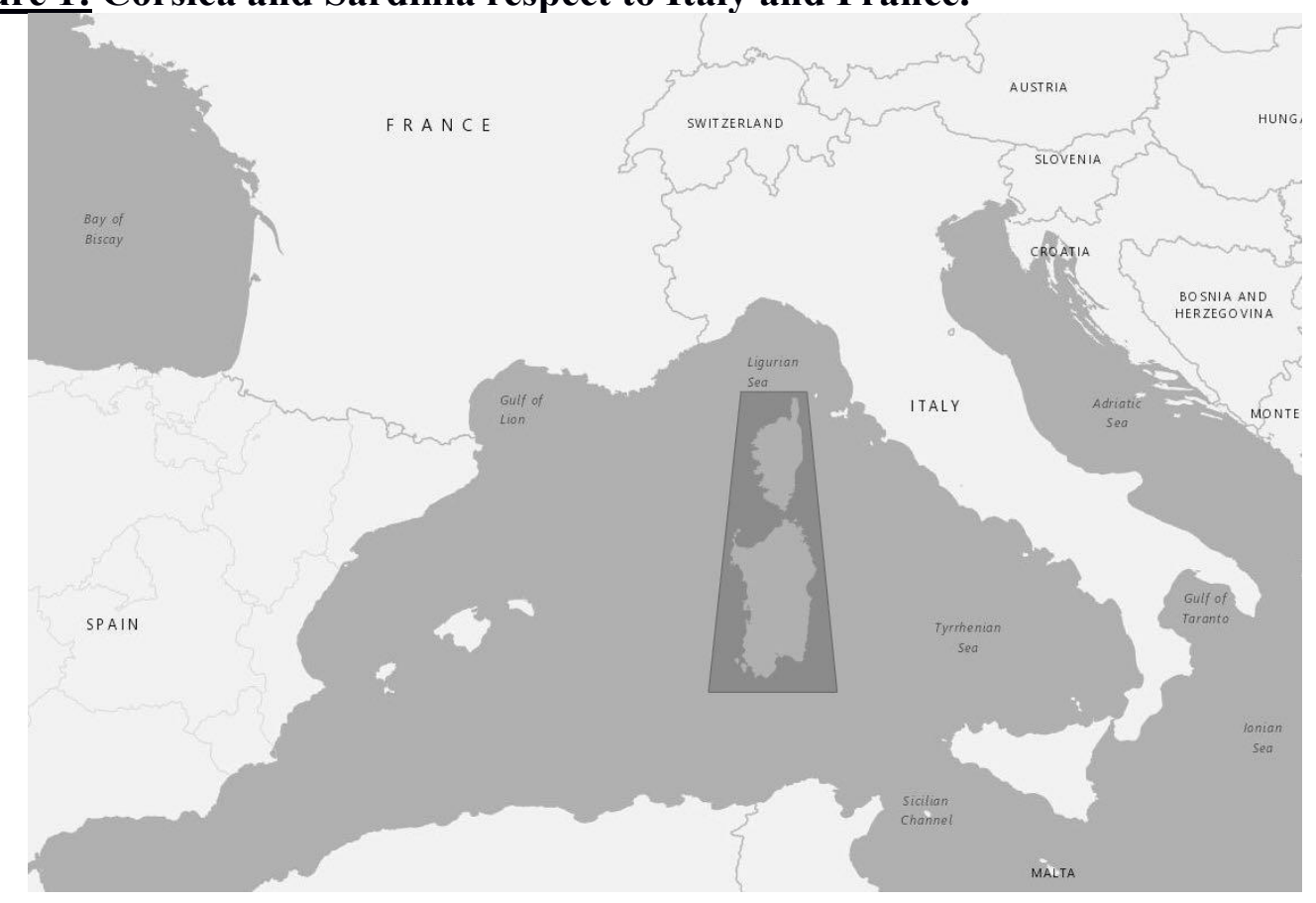

Source: (C) Marcel A. Farinelli.

The present article aims to help fill this gap, moving a step further with respect to what Steinberg, Edquist, and Holmén have suggested about the role of islandness for continental nationalisms. My argument is that the Mediterranean islands offered rhetorical and symbolic elements useful for the construction of mainland national identities, largely because islandness, from a continental point of view, was able to conserve authenticity. I will make this argument by drawing upon Sardinia and Corsica as case studies.

The short distance that separates Sardinia from Corsica and vice versa suggests that they should not be considered simply as two juxtaposed islands, but rather as an archipelago (for the archipelagic perspective, see Stratford et al., 2011; Pugh, 2013). Beyond geography, culture, and biology, one of the common elements that unite both islands is the role played in the formation of 
the nation-states to which the two are linked: Italy for Sardinia, and France for Corsica. Both islands contributed to the process of codifying a national identity by providing crucial symbolic components to the mythology of the new, invented nation-state. In spite of this, both islands experienced similar problems of integration within their respective mainland states, with regionalist or nationalist movements that have been a relevant political force since the second half of the $19^{\text {th }}$ century (Fazi, 2009; Roux, 2013). This led to the development of two kinds of nationalisms: insular and mainland.

However, the presence of a third nationalism makes the situation even more complex. I am referring to Italian nationalism in Corsica, and Catalan nationalism in Sardinia. The former was relevant until the Second World War, because Italian nationalists considered Corsica part of Italy. In Sardinia, Catalan nationalism was, and to some extent still is, present. The island belonged to the Crown of Aragon, and then - until the $18^{\text {th }}$ century - to the Spanish Monarchy. The Catalanspeaking town of Alghero (L'Alguer, in Catalan), on the Northwest coast, is claimed as part of the Catalan Countries, the nation dreamt of by the Catalan pan-nationalists living in Spain, France, and Italy (Farinelli, 2014a).

My intention is not to discuss the island's nationalist movements, but rather the role played by both islands for the three mainland nationalisms: Italian, French, and Catalan. I will do this by analysing some national characteristics that entered the collective nationalist imaginary, as interpreted by mainland intellectuals as part of the national identity, and, in addition, some moments regarded as highly symbolic or rhetorically relevant in the making of a fully matured nation. The intention is not so much to assert a definitive conclusion, but rather to help establish a stepping stone towards a general theoretical framework that might orient future scholars regarding mainland nationalism in island contexts.

\section{Sardinia and its multiple nationalisms}

Sardinia is the second-largest Mediterranean island and has been part of the Italian state since its establishment in 1861. Nineteenth-century Sardinian historiography described the island's past as a succession of external dominations (Manno, 1825-1827), and even if this conception is now obsolete, it is useful for understanding how the island took part in the formation of modern Italy. For $19^{\text {th }}$-century Sardinian intellectuals, all invasions were considered catastrophic, but especially those that interrupted a supposed natural link with the Italian Peninsula. The last of the invaders described as having alienated Sardinia from Italy were the Catalans in the $14^{\text {th }}$ century, regardless of the fact that, when Southern Italy was part of the Spanish Monarchy $\left(15^{\text {th }}-18^{\text {th }}\right.$ centuries $)$, contacts between Sardinia and other Spanish-controlled crownlands such as Sicily increased. This fact suggests that, when intellectuals in the 1800s talked about an interruption in the relationships with Italy, they meant the isolation of Sardinia from a supposed Italian-ness that existed in the non-Spanish part of Italy.

Catalan forces arrived on an island split between the Republics of Genoa and Pisa and, although acting as protectors of the oppressed Sardinians, waited almost 150 years before gaining full control. While Pisa and Genoa obtained concessions from the Indigenous kingdoms that had ruled the island since the $10^{\text {th }}$ century, the Catalan King of Aragon James II was named king of the Regnum Sardiniae et Corsicae by the Pope, who considered both islands a fief of the Papacy. The sense of kingdom was finally limited to Sardinia as a whole, which was conquered after a long war against Pisans, Genoese, and their Sardinian allies. Until the $18^{\text {th }}$ century, the island was part of 
the Spanish Empire, and the influence of Iberian culture was so intense that even today the Hispanic cultural heritage is evident. The Catalan language spoken in Alghero is part of this heritage.

In the aftermath of the War of the Spanish Succession (1701-1715), Sardinia fell into the hands of the Dukes of Savoy. This moved Sardinia from a Catalan and Spanish-speaking background to a generic Italian context. The island kingdom gave the House of Savoy the title of Kings, and this fact has been interpreted by the Italian nationalist historiography as the first step towards the achievement of a unified Italy. Sardinia returned to the arms of its motherland after centuries of separation, and from 1848 its sovereigns led the Risorgimento. Even though island culture was deeply distinct from northern mainland forms, the Kingdom of Sardinia was considered the cradle of the new Italian State, which was created by annexing the other existing Italian states to this realm. This is a first characteristic theme that suggests the non-secondary, even if merely formal, role played by Sardinia in the formation of modern Italy. When in 1861 Victor Emanuel II declared himself King of Italy, he acted as the King of Sardinia, an insular monarch who created one of the most important European countries in the new world of nations.

Such an origin had an important consequence for historiography. Sardinian intellectuals during the $19^{\text {th }}$ century were codifying an insular national identity, but this process changed completely during the 1840 s, when the Sardinian royal family assumed the role of leaders of the Italian unification process. Until then, the Sardinian elite, which at first opposed the new dynasty, envisioned the idea of a glorious future for the royal family and their nation, Sardinia. For this reason, the idea of an Indigenous and fully sovereign power that had its origin in the island was asserted, and even false manuscripts were manufactured to underpin this theory (Marroccu, 1997, 2009). These documents were the Carte d'Arborea, and at that time were deemed the only primary sources available concerning the history of Arborea, the Indigenous kingdom that had led the resistance against Catalan invasion. The papers were used to demonstrate that Sardinia had had its own language and culture long before the arrival of Catalan troops. But when the kings of Sardinia, who traditionally had been quite reactionary and loyal allies to the Habsburg Empire, embraced Liberalism and began to act as leaders of the Risorgimento, the Sardinian elite changed their interpretation of their own national history. This happened mostly after 1848, when the same island elite asked to merge the realm with other mainland territories ruled by the House of Savoy (Piedmont, Liguria, Savoy, Nice, and Aosta Valley). As a result, all those territories were named the Kingdom of Sardinia and placed under a unique and centralized jurisdiction, while the island's own institutions, such as the Parliament, were abolished (Brigaglia \& Marroccu, 1995; Accardo \& Gabriele, 2011). From then on, Sardinian intellectuals began to speak about an island which, in the past, had had a strong bond with the Italian peninsula; even the false manuscripts were used to confirm this historiographical perspective. Sardinia was not only the origin of an independent power, but the Carte d'Arborea also provided evidence for deep links with Italy. The discovered documents, despite being written mainly in Sardinian and Latin, contained some fragments in Italian, and in this way they were regarded as among the earliest texts in the national language. Thus, besides its role as the juridical entity that unified Italy, for some years Sardinia was depicted as the cradle of the Italian language, until, in 1870, the outstanding classicist Theodor Mommsen proved that the Carte were a fake.

The second element that deserves to be mentioned is the national anthem adopted by the Kingdom of Italy in 1861. It was the same as the royal march of the Kingdom of Sardinia, and its lyrics were composed by an island intellectual in the Sardinian language: Cunservet Deus su Re / S'Hymnu Sardu Nationale ('God save the King / Sardinian National Anthem'). Composed in 1834, it was part of the intellectual process aimed at promoting a Sardinian national identity, and, in fact, 
the same author, Vittorio Angius, was a key figure in this ideological process. Ex-priest, historian, and eclectic intellectual, he was among those convinced of the inherent authenticity of the Carte. The hymn, far from being a revolutionary piece like the Marselliaise, celebrated more the dynasty than the Nation and, after the House of Savoy assumed the leadership of the Risorgimento, and even when unification of Italy was finally successfully achieved, the Sardinian royal march continued to be played. It was last performed in 1937, the year after Mussolini invaded Ethiopia and established the Italian Empire. When the Italian Republic was declared in 1946, the Constitutional Assembly voted for a new national anthem, written in Italian during the Risorgimento. The author of the lyrics was Goffredo Mameli, an aristocrat of Sardinian origins living in Genoa, who died while defending the Roman Republic of Mazzini and Garibaldi, a failed attempt to create a republican and unified Italy in 1848-1849.

Although Sardinia is in a peripheral position with respect to the Italian peninsula, in a rhetorical sense it is at the core of modern-day Italy. But, paradoxically, between the end of the $19^{\text {th }}$ century and the beginning of the $20^{\text {th }}$, Sardinia was considered a territory not solidly assimilated with the mainland, a place where Italian was hardly spoken and where state authorities, due to the presence of rural banditry and major difficulties with internal connections, were unable to fully exercise its sovereignty. The island was considered more as a colony, in a country that experienced three great defeats $(1887,1895$, and 1896) in the attempt to secure an overseas colonial empire. The same colonial troops were engaged to fight banditry, while some authors referred to the island as the 'Italian Africa', with the intention of criticizing government attitudes towards the patterns of Sardinian life (Cimbali, 1907). Outstanding Italian anthropologists, such as Giuseppe Sergi (1895) and Alfredo Niceforo (1897), described insular inhabitants as wild, uncivilized, and natural criminals, while writers such as Paolo Orano (1892) used the same clichés but without scientific pretences. For all of them, islandness was in itself a negative value.

There was one exception: the novelist and poet Gabriele D'Annunzio. He visited Sardinia in 1882, and found in it an uncorrupted and authentic civilization (Mulas, 2009). Sardinian shepherds, for D'Annunzio, were indeed barbarians and primitives, but precisely thanks to those features, they had not been corrupted by modern civilization, and were acting as if they were still living under the Roman Empire. This famous poet wrote verses imitating the Sardinian language, which he considered ancient and untouched by modern usage; although D'Annunzio's pastiche was a mix of Latin and Spanish, the result sounded so exotic that it could be considered as 'authentic Sardinian' by the Italian public. In the post-Risorgimento context, when most of the actual Italy was in the hands of the House of Savoy, Italian-ness was no longer related to an oppressed people fighting for liberty, but to a modern nation, destined to establish a new Roman Empire (Banti, 2011; Gentile, 2006). D'Annunzio was one of the major intellectuals who, as a radical nationalist, made a fundamental contribution to the forging of this image. For him, Sardinians represented an inspiration: islandness had ensured the preservation of virtues and values that, at the end of the $19^{\text {th }}$ century, D'Annunzio considered to have disappeared from the mainland.

Nonetheless, D'Annunzio was an exception, and the island continued to be associated with underdevelopment and loose criminal behaviour. To use Michael Herzfeld's concept, it represented a 'cryptocolony' (Herzfeld, 2002), and, drawing upon Gillis's reflections (2004, pp. 123-124), the modern association of islandness with backwardness had made Sardinia, in the eyes of the educated Italian elite, a place more similar to an exotic colonial dependency than to a region of a European country. This connection between islandness and wildness turned positive during the the First World War, when the Italian Army Chief of Staff created a unit composed predominantly of Sardinian shepherds and peasants: the Sassari Brigade. It was converted into an elite unit that 
proved to be very effective in the cruel Alpine battlefields, so Sardinians passed from being held as a criminal race to being hailed as heroes: the myth of the so-called 'brave Sardinian soldiers' was created (Fois, 1981). From this moment, the Sassari Brigade was part of the national mythology about the Great War, and Sardinians were considered virtuous soldiers, true natural warriors, the only ones celebrated in this way by the Italian Army. The flag, the insignia and the hymn adopted by this unit do not show any element related to Italy, and its motto, Sa vida pro sa patria, was pointedly in Sardinian, not in Italian. Today, during the annual military parade held in Rome every $2^{\text {nd }}$ of June to celebrate the Festa della Repubblica, the most important national festivity, the Brigade marches. chanting its hymn in Sardinian. With the exception of one Italian flag, it displays only Sardinian symbols.

In this respect, it is important to highlight one thing. Since the Risorgimento was a process in which only a small proportion of Italian population participated, the First World War was considered by Italian nationalists the crucial moment for the formation of a national identity, replacing the National Revolution that $19^{\text {th }}$-century patriots had been unable to accomplish (Gentile, 2006, p. 167). The Sassari Brigade was thus an important element for spreading the sense of Italian-ness among islanders.

This attitude applies especially to the Fascist period (1922-1943). In Mussolini's political agenda, national identity was a key issue and one of the main objectives of the Blackshirts was to assert the centrality of the Nation. The myth of the 'brave Sardinian soldiers', which represented a kind of ideal combatant - fierce, proud, and eager to obey-was a message and an image that held great attraction to the Fascist regime. This image had been created during the 1914-1918 war by military authorities, who used it for propaganda, and was spread by newspapers and commemorative books (above all, Riccio, 1917-1920). During the interwar years, the publication of memoirs further developed this ideal, and in Fascist mythology the Sardinian soldiers represented a kind of prototype for the new Italian, the superior race that would rule the Mediterranean in the Fascist revival of the Roman Empire. The island was considered a cradle of virility and rurality, values attributed to the Ancient Roman society considered the core of the new Italian identity promoted by Mussolini (Nelis, 2007). Much like D'Annunzio before him, Mussolini was convinced that islandness would automatically guarantee the preservation of authenticity, and that Sardinians were and would remain uncorrupted by such modern ideologies as socialism. To symbolize this connection between the islanders' purity and rusticness and the new Italian identity, he ordered that the Blackshirts' uniforms be made using raw Sardinian sheep wool.

The island, however, was also important for mainland Catalan nationalism. During the $19^{\text {th }}$ century, Catalan intellectuals began to be interested in the Catalan-speaking enclave of Alghero, as for them it served as an example of the resilience of their own national identity, strongly based on language use. The Sardinian town had remained isolated from the rest of the Spanish territories since the beginning of $18^{\text {th }}$ century, and this characteristic was said to have granted the survival of an uncorrupted form of Catalan, which, for nationalists based in Barcelona, explicitly meant not influenced by Spanish. For this reason, Alghero played a role in the heated debate on the relationships between the Catalan and Spanish languages.

At the beginning of the $20^{\text {th }}$ century, Ramon Menéndez-Pidal, an outstanding philologist and staunch Spanish nationalist, affirmed that Algherese Catalan was influenced by Spanish, and so this proved that Catalan had evolved from the Castilian language - and therefore was a dialect. Meanwhile, his rival, the priest Josep Maria Alcover, a self-taught linguist and folklorist from Majorca, claimed that those elements Menéndez-Pidal considered Spanish were actually Sardinian and Italian, thereby proving the fact that the Catalan spoken by islanders in Sardinia was not 
influenced by Spanish (Farinelli, 2014b, pp. 108-110). In such an intellectual confrontation concerning origins and authenticity, islandness was considered the factor that made possible the survival of the language in its purest version, and this was considered by Catalan nationalists the perfect proof of the existence of a Catalan nation. In contrast, for Spanish nationalists, insularity proved how an Algherese variant, believed to be uncorrupted in comparison with the mainland Catalan language, was closest to Spanish, an unquestionable fact that denied the existence of Catalonia as a nation.

It is evident that Catalan nationalists found in this enclave some elements of their national imaginary. From their point of view, they confirmed the stirring survival of the Catalan-ness, and of its glorious past.

\section{Figure 2: Alghero and the Catalan Countries.}

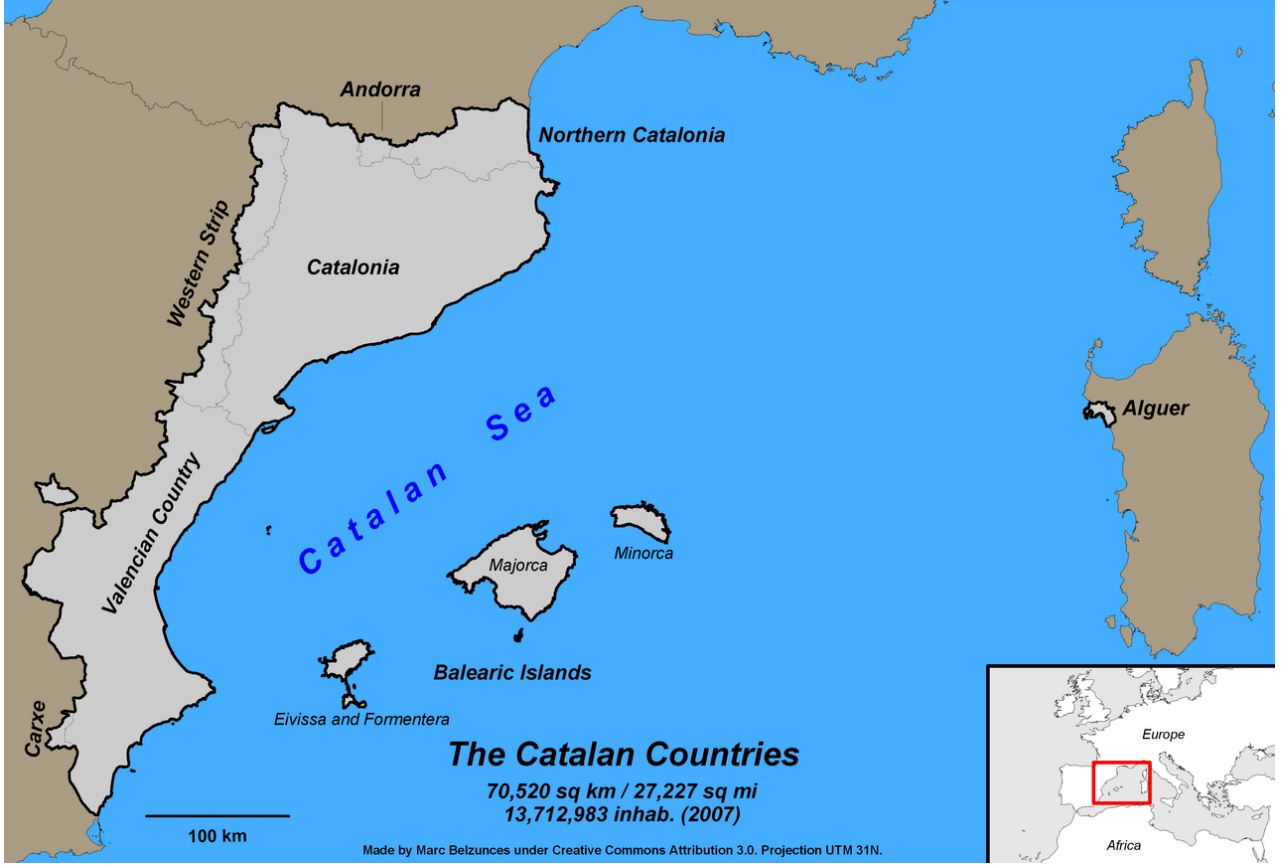

Source: (C) Marc Belzunces. 2007,

https://ca.wikipedia.org/wiki/Pa\%C3\%AFsos_Catalans\#/media/File:Ppcc2007english.png

\section{Corsica and its numerous nationalisms}

Corsica's historiographical tradition repeated the pattern of Sardinia. After Greeks, Romans, and Pisans, the island was merged by the Papacy with Sardinia in the Regnum Sardiniae et Corsicae, and assigned to the Catalan-Aragonese. But the island was never conquered by the Crown of Aragon, and finally, during the $15^{\text {th }}$ century, it fell into the hands of Genoa.

But Genoese control had clear limits, especially as the power of the Republic faded. The geopolitical situation of the island changed between 1729 and 1769, when, in practical terms, the Corsican Revolution brought Genoese domination to an end. The revolution was a long and complex process that saw the involvement of the most important European powers. Finally, the Kingdom of France managed to take control of the island in a deal with Genoa. Due to this involvement, the Corsican insurrectional dynamic has influenced the fundamental moment in the formation of modern-day France: the French Revolution. 
The revolt in Corsica started as a protest against a tax considered illegal, and it ended with an attempt to create a modern state. The core argument of the insurgents was that Genoa was acting as a despotic power, infringing upon the pact that, according to a popular belief, regulated the relationship between the island and the Republic. Soon the protest turned into a revolution that lasted 40 years. The key figure of these events was Pasquale Paoli. He was leader of the insurgents in 1755-1769, with the title of Generale, and faced the French expedition that ended the revolt. After the heroic Battle of Ponte-Novo, Paoli went into exile in London, only to return in 1790, acclaimed as a hero by both French and Corsican revolutionaries. But in 1794, he broke with revolutionary France, accepting a British protectorate (the Anglo-Corsican Kingdom, which lasted until 1797, when France regained control of the island). In 1795, Paoli left Corsica, living the rest of his life as a refugee in London, receiving a pension from the British King. Since it is impossible to discuss all these events in detail, we shall just highlight some aspects of them.

The first element to take into account is that the Corsican rebels tried to build an independent state based upon national and popular sovereignty, before the American and French revolutions. The Corsican revolutionaries considered the Genoese domination to be illegitimate, and claimed that sovereignty was a prerogative of the Corsican people, not of foreigners. Sovereignty was exercised through the evolution of an insular institution, the consulta, an assembly held from 1264 on a local basis but which occasionally involved the whole island. The local consulta dealt with different issues, such as the distribution of common land, but general assemblies were organized during periods of war or rebellion, to resolve a feud or discuss war strategies. During the revolt, these assemblies were centralized and regulated, until they evolved into a national institution representing the entire island. In order to legitimize the power that Corsican rebels de facto exercised, they created a legal framework, transforming traditional institutions into a new kind of political system. Thus, during the revolt, two major laws were drafted. The first, in 1736, was a kind of fundamental law for the Kingdom of Corsica, under the rule of a German nobleman, Theodor Von Nehuoff (Theodor I). The second, drafted in 1755 when the kingdom proved to be unviable, represented an important innovation. This document, lost for almost two centuries in the island archives, can be considered a first attempt to establish a representative government, before the American Confederal Constitution of 1777 and the French Declaration of the Rights of Man and of the Citizen of 1789, for which it represents a direct precedent (Carrington, 1973, 1986).

Even if many scholars continue to assert the primacy of American or French laws, the island was during the revolution a laboratory where new forms of political organization, such as the nation-state model, were developed. The representative system organized by the Corsicans included male suffrage, and any man over 25 could be elected to the legislative assembly (Dieta). Moreover, executive, legislative, and judiciary powers were harmonized in a system of checks and balances, inspired by Montesquieu's Esprit des Lois. It is broadly known that Jean Jacques Rousseau was involved in an attempt to write a constitution, and even if his involvement is seen as a means of discrediting the Corsican leaders, the philosophe was sincerely interested in the Corsican Revolution (Vergé-Franceschi, 2005, pp. 322-327). As Dorothy Carrington (1973, p. 483), the British anthropologist and writer, who first defended the importance of Paoli's political innovations, stated, the Corsican "constitution issued from a convergence of the Enlightenment, as represented by Montesquieu, and of Corsican political traditions, rooted in the distant past, and significantly developed during the national struggle of the preceding twenty-five years". Paraphrasing the famous Rousseau quotation, in this sense the island astonished Europe, but the 
importance that historiography gave to the American and French revolutions made this island precedent invisible.

The second element to be mentioned is that during the war against the Genoese and, above all, the French, Corsican rebels were seen, mainly by the British, as an Indigenous people resisting a foreign invasion and a despotic power. British fascination with Mediterranean and Classic culture were in part responsible for this mythification. Islandness granted the preservation of classical virtues, and in a context of war between United Kingdom and France (the French and Indian War, 1754-1763), British intellectuals praised the determination of the 'Brave Corsicans' to fight for their liberty (Vergé-Franceschi 2005, pp. 317-319). The Scottish writer James Boswell, who in 1765-1766 travelled to Corsica and met Paoli, referred to Corsicans by this label. Boswell in 1768 published a book about this journey, adding the memoirs of Paoli, and in 1769 edited a volume that celebrated the revolution. The books were both bestsellers, and Boswell was such an enthusiastic propagandist of the revolutionary's struggle that he even attended a masquerade ball for the 1769 Shakespeare Jubilee dressed as a Corsican chieftain. All these activities spread a veritable Corsican fascination among British society (Cini, 1998), who during the French and Indian War suffered resounding defeats thanks to the guerrilla tactics of France's Indigenous allies. Many dreamed about the islanders fighting for freedom against French troops, and the Corsican rebels were seen as the prototype for the Patriot. The modern sense of this term, and the concept of patriotism, in part has its origins in how the British and French looked at this struggle of natives defending their homelands and liberties from a foreign invasion. They were the 'good savages', seen as the incarnation of Ancient Romans or Greeks in the context of the late- $18^{\text {th }}$ century obsession with neoclassicism (Ucelay-Da Cal, 2009, pp. 224-235).

Paoli did his most to create this image. The title of Generale used by Paoli was the same adopted by all his predecessors at the head of the revolution, including his father. But Paoli transformed this role from a military one to one of political leadership, presenting himself as a head of state. He built up a Corsican state with a representative government, the first based on popular sovereignty and separation of powers, acting as Father of the Nation, as Boswell labelled him. Thanks to this writer, Paoli was turned into an archetypal patriot, depicted as a modern-day Themistocles. Other writers, such as Rousseau, Pommereul, and Voltaire, referred to him in similar terms, and the myth of Paoli, the enlightened hero who led the native islanders against despotic mainland invaders, spread into British North America. It served as an inspiration for the settlers' struggle against colonial domination, and even today there are a number of toponyms referring to Paoli in the United States (Vergé-Franceschi, 2005, pp. 383). The fact that the Corsican general broke with Revolutionary France to accept British protection faded his myth, so American and French revolutionaries almost forgot him. But, before these events Paoli and his Brave Corsicans were undoubtedly an inspiration for North American patriots (Anderson, 1927; Beretti, 1974).

With reference to Corsica, leading generals, and the spread of revolution, it is impossible not to mention Napoleon Bonaparte. Since this figure is well known, and it is impossible to cover the subject in a few paragraphs, I will mention him only briefly. His Corsican origins are widely known, and his family was involved in the fight against Genoa and France. As an adolescent, Napoleon dreamed of leading another revolt against the French occupiers. For the young Bonaparte, Paoli was a hero, and he saw himself as a successor to the older revolutionary. How Napoleon's island origins influenced his career is a question that cannot be explored here, but the perception would be that this factor played an important role, as stressed by some of his recent biographers (e.g., Dwyer, 2008). 
But there is yet another element of Corsican origin that is important for French national mythology: the maquis. This word is a translation of the term macchia, which in the Corsican language indicates the scrub vegetation that covers a great part of the Corsican landscape and is spread all over the Mediterranean. This inhospitable terrain is the ideal place to escape from public authorities, and many people found protection in the maquis, from the Brave Corsicans to bandits who had committed a vendetta. During the $19^{\text {th }}$ century, a person who moved to live outside the village as an outlaw due to a blood feud was said to have 'taken to the bush' (darsi alla macchia). This was a common practice in rural areas, and the Corsican bandit became a figure widely known throughout French and European society (Wilson, 1988). Thus arose the romantic image of a man who, for honour, lives in the mountains of the Mediterranean island, escaping from unjust authority. This cliché was forged by novelists and travellers, and even a tourism economy grew up exploiting British voyageurs wishing to see bandits. This myth served as inspiration and as a powerful propaganda instrument for the members of French Resistance during the Second World War, who called themselves maquis (Choury, 1956). As in the case of $19^{\text {th }}$-century outlaws, they were bandits d'honneur (bandits of honour), and as in that of $18^{\text {th }}$-century rebels, they were fighting for freedom. The liberation of Metropolitan France started from Corsica in 1943, and the metaphor of the maquis was so powerful that today the word usually refers to all members of the French Resistance. For the most, however, the history of the Liberation of France began with DDay, and the island origins of the term have nearly vanished.

To make the matter even more complex, Corsica had a role in the Risorgimento, since it was considered part of the envisioned Unified Italy. Corsican is an Italic language, and Italian cultural influence ran deep in the island. During the Risorgimento, many of the patriots persecuted by the governments of the anti-nationalist Italian States escaped to Corsica. Many of them agreed that Corsicans were able to maintain their Italian-ness in spite of French domination. One of these was Niccoló Tommaseo. Linguist, writer, and folklorist, he considered Corsicans to be uncorrupted by modernity, which he termed frenchification, the imposition of French language and culture. Due to its islandness, Corsicans were able to maintain an allegedly authentic Italian identity, but above all they were fighting for more than a century first against the despotism of the Genoese Republic and then against French occupation. For these reasons, the Corsicans represented to Tommaseo the model upon which Italian identity would be forged (Cini, 2009). The Corsican Revolution and the figure of Paoli would act as the inspiration for the Italian Risorgimento, as Tommaseo (1846) stated in the introduction to a volume that included the correspondence of the Generale. Moreover, as one of the most prominent linguists on the Italian Peninsula, Tommaseo defended the theory that Corsican, due to insularity, was the purest of the Italian dialects.

Like Tommaseo, Gian Domenico Guerrazzi (1857, 1860) used Paoli and his Brave Corsicans as an example for the Italian struggle against the Austrian Empire. Ultimately, however, Corsica remained a French territory, and this fact nourished an Italian-oriented nationalism, the socalled 'Irredentism'. Some strata of Corsican society dreamt of joining the unified Italy, while Italian nationalists claimed the island as one of the unredeemed parts of their homeland. This current grew strong under the Fascist regime, during which Corsica was considered an important stepping stone for the building of an Italian Mediterranean Empire. After the Italian fiasco in the Second World War, however, irredentism nearly disappeared from island politics, while, perhaps significantly, Italian historians failed to investigate the subject because they wished to avoid any accusation of Fascist nostalgia. In this way, the role of Corsica in the Risorgimento was not recognized, in a parallel way to the circumstances of Sardinia. 


\section{Conclusions}

From a continental perspective, islands are conceived as collective spiritual fortresses where purity - significantly, a supposedly national purity - resists outside threats as well as places where a new world can be imagined (Baldacchino, 2005; Gillis, 2004; Waterston, 1998). Islandness has indeed been so key to the Western cultural imagination that "The metaphoric deployment of 'island' is, in fact, so enduring, all-pervading and commonplace that a case could reasonably be made for it as the central metaphor within western discourse" (Hay, 2006, p. 26). The island role in Italian, French, and Catalan nationalism is evident: islands served continental nationalist intellectuals as storehouses for national values, preserved uncorrupted by the sea, and at the same time they worked as sources of inspiration for patriotic myths and metaphorical elements of the national imaginary. Even if this process, as we have seen for $19^{\text {th }}$-century Sardinia, was also driven by the islanders themselves, it was eventually managed from a continental point of view. It served as a mainland nation-building and state-building tool, even if elements such as the figure of Pasquale Paoli or the Sassari Brigade are also important myths for island nationalism.

Nevertheless, the island origins of such elements of the national imaginary have been forgotten, or removed. Sardinia and Corsica were (and are) perceived as exotic places in the eyes of Italian, French, and Catalan intellectuals, and this produced (and produces) an obstacle for the integration of island history into mainland national historiography. In this way, the contribution of both islands to the construction of national imaginary is not properly recognized.

This is a case completely different with respect to that of the Baltic islands of Gotland (Sweden), and Saaremaa and Hiiumaa (Estonia), analyzed by Edquist and Holmén. These islands played a similar role as that of Sardinia and Corsica, to the point that "the cultural and historical landscapes of Gotland and Saaremaa have also become national icons, perceived as relics of how Sweden and Estonia looked in the past" (Edquist \& Holmén, 2015, p. 402). Unlike the two Mediterranean islands, however, the Baltic islands are perceived by Estonian and Swedish historians as places that have played an important role in the histories of their respective countries, and not as exotic isles. The reason for this difference lies in the fact that, while the three Baltic islands share a common cultural and historical tradition with the mainland state to which they belong, Corsica and Sardinia, as we have seen, do not, or at least not entirely. In addition, the decrease of contact between the city of Alghero and Catalonia, as between Corsica and Italy, experienced since the 18th century, converted both islands into mythical places that Catalan and Italian nationalists believed were capable of preserving key elements of the authentic national identity that had been lost or corrupted on the mainland.

These characteristics, and the opposing nationalisms that have been present in Corsica and Sardinia, complicated the task of merging the past of the two islands into one national history with those of their respective mainlands. For this reason, isolated in the sea and imagined outside of history, both islands represented sources of inspiration for the Italian, French, and Catalan national mythologies rather than, as is the case of Gotland with respect to Sweden, an important element in the historical evolution of the country.

\section{Acknowledgments}

I would like to thank Adam Grydehøj, Ana Martín, Gavino Balata, Mariana Welti, and three anonymous scholars who reviewed this text. Without them, this article would never have been written. 


\section{References}

Accardo, A. \& Gabriele, N. (2011). Scegliere la patria. Classi dirigenti e risorgimento in Sardegna. Roma: Donzelli.

Anderson, G.P. (1927). Pascal Paoli, an inspiration to the Sons of Liberty. Publications of the Colonial Society of Massachusetts, 26, 180-210.

Baldacchino, G. (2010). Island enclaves: Offshoring strategies, creative governance and subnational island jurisdictions. Montreal: McGill-Queen's University Press.

Baldacchino, G. (2006). Islands, Island Studies, Island Studies Journal. Island Studies Journal 1(1), 3-18.

Baldacchino, G. (2005). Islands-Objects of Representation. Geografiska Annaler, 87 B(4), 247251. https://doi.org/10.1111/j.0435-3684.2005.00196.x

Baldacchino, G. (2004). Autonomous but not sovereign? a review of island sub-nationalism. Canadian Review of Studies in Nationalism, 21(1), 77-91.

Baldacchino, G., \& Hepburn, E. (2012). A different appetite for sovereignty? Independence movements in subnational island jurisdictions. Commonwealth \& Comparative Politics, 50(4), 555-568. https://doi.org/10.1080/14662043.2012.729735

Banti, A.M. (2011). Sublime madre nostra: la nazione italiana dal risorgimento al fascismo. Roma-Bari: Laterza.

Beretti, F. (1998). Quatre portraits de Pascal Paoli par des artistes britanniques. Bulletin de la Société des Sciences Historiques et Naturelles de la Corse, 682/683, 97-106.

Beretti, F. (1974). Pascal Paoli inspire les patriotes americans. Bulletin de la Société des Sciences Historiques et Naturelles de la Corse, 611, 4-81.

Boswell, J. (1769). British Essays in Favour of the Brave Corsicans. London: Edward and Charles Dilly.

Boswell, J. (1768). An Account of Corsica. London: Edward and Charles Dilly.

Brigaglia, M. \& Marroccu, L. (1995). La perdita del Regno. Roma: Editori Riuniti.

Carrington, D. (1986). The Achievement of Pasquale Paoli and its Consequences. Proceedings of Consortium of Revolutionary Europe, 15, 56-69.

Carrington, D. (1973). The Constitution of Pascal Paoli (1755-1769). The English Historical Review, 88(348), 481-503. https://doi.org/10.1093/ehr/LXXXVIII.CCCXLVIII.481

Chourry, M. (1956). Tous bandits d'honneur. Résistances et libération de la Corse. Paris: Éditions Sociales.

Cimbali, E. (1907). La Sardegna è in Italia? Pregiudizi sul regionalismo. Rome: Bernardo Lux

Cini, M. (2009). Niccoló Tommaseo e l'esperienza dell'esilio. In M. Cini (Ed.), Corsica e Toscana nell'Ottocento (pp. 125-151). Genova: Edizioni Culturali Internazionali.

Cini, M. (1998). La nascita di un mito. Pasquale Paoli tra '700 e '800. Pisa: Edizioni della Biblioteca Franco Serrantini.

Depraetere, C. \& Dahl, A.L. (2007). Island Locations and Classifications. In G. Baldacchino (Ed.). A World of Islands (pp. 57-106). Charlottetown: Institute of Island Studies.

Dwyer, P. (2008). Napoleon, the path to power. Yale University Press.

Edquist, S. \& Holmén, J. (2015). Islands of Identity: History writing and identity formation in Five island regions of the Baltic Sea. Stockholm: Södertörn University.

Farinelli, M. A. (2014a). The invisible motherland? The Catalan-speaking minority in Sardinia and Catalan nationalism. Studies on National Movements, 2.

Farinelli, M.A. (2014b). Història de l'Alguer. Barcelona: Libres de l'Índex.

Fazi, A. (2009). La recomposition territoriale du pouvoir: les régions insulaires de la Méditerranée occidentale. Ajaccio: Albiana. 
Fois, G. (1981) Storia della Brigata Sassari. Sassari: Gallizzi.

Gentile, E. (2006). La grande Italia: il mito della nazione nel XX secolo. Roma-Bari: Laterza.

Gillis, J. (2004). Islands of the Mind: How the Human Imagination Created the Atlantic World. New York: Palgrave Macmillan.

Grydehøj, A. (2016). Toward Subnational Democracies of Scale: Tensions between Democratic Legitimacy, Legality, and Effective Governance. Geopolitics, 21(1), 22-42. https://doi.org/10.1080/14650045.2015.1114918

Guerrazzi, F.D. (1860). Pasquale Paoli ossia la Rotta di Pontenuovo. Milan: Guigoni.

Guerrazzi, F.D. (1857). La torre di Nonza. Turin: Guigoni.

Hay, P. (2006). A Phenomenology of Islands. Island Studies Journal, 1(1), 19-42.

Hepburn, E. (2012). Recrafting sovereignty: lessons from small island autonomies? In M.G. Gagnon, \& M. Keating (Eds). Political autonomy and divided societies: Imagining democratic alternatives in complex settings (pp. 118-133). Basingstoke: Palgrave Macmillan. https://doi.org/10.1057/9780230365322_8

Herzfeld, M. (2002). The Absent Presence: Discourses on Crypto-Colonialism. South Atlantic Quarterly, 101(4), 899-926. https://doi.org/10.1215/00382876-101-4-899

Khoo, S.L., Samat, N., Badarulzaman N., \& Dawood S.R.S. (2015). The promise and perils of the island city of George Town (Penang) as a creative city. Urban Island Studies, 1, 20-34. https://doi.org/10.20958/uis.2015.2

Lawrence, D.H. (1999 [1921]). Sea and Sardinia. Penguin: Londres.

Manno, G. (1825-1827). Storia di Sardegna. Turin: Alliana e Paravia.

Marroccu, L. (2009). Theodor Momsen nell'isola dei falsari. Cagliari: CUEC.

Marroccu, L. (1997). Falsi e falsari nella Sardgna del XIX secolo. Cagliari: AM\&D.

Mulas, F. (2009). La serenità dell'interludio. D'Annunzio, Scafroglio, Pescarella e la Sardegna. Cargeghe: Documenta.

Nelis, J. (2007). Constructing Fascist Identity: Benito Mussolini and the Myth of

Romanità. Classical World C, 100(4), 391-415. https://doi.org/10.1353/clw.2007.0069

Niceforo, A. (1897). La delinquenza in Sardegna. Palerm: Sandron.

Orano, P. (1892). Psicologia della Sardegna. Rome: Tipografia della Casa Editrice Italiana.

Pugh, J. (2013), Island Movements: Thinking with the Archipelago. Island Studies Journal, 8(1), 9-24.

Rodd, A. (2016). Adapting postcolonial societies: Fiji and the Solomon Islands in the Pacific. Island Studies Journal, 11(2), 505-520.

Roux G. (2013) La nationalisation des périphéries. Fragments du processus de construction nationale en Corse et Sardaigne. Paris: L'Harmattan.

Sergi, G. (1895). Origine e diffusione della stirpe mediterranea. Induzioni antropologiche. Rome: Società Editrice Dante Alighieri.

Steinberg, P.E. (2005) Insularity, sovereignty and statehood: the representation of islands on portolan charts and the construction of the territorial state. Geografiska Annaler, $87 \mathrm{~B}(4)$, 253-265. https://doi.org/10.1111/j.0435-3684.2005.00197.x

Stratford, E., Baldacchino, G., MacMahon E., Farbotko C. \& Harwood A. (2011). Envisioning the archipelago. Island Studies Journal, 6(2), 113-130.

Tommaseo, N. (1846). Lettere di Pasquale de Paoli. Florence: G. P. Viesseux

Tommaseo, N. (1841). Canti popolari toscani, corsi, illirici e greci, vol II. Venice: Girolamo Tasso. 
Ucelay-Da Cal, E. (2009). Agustina, la dama del canon, el topos de la heroina falica y el invento del patriotismo, in I. Castells Olivàn, M. G. Espigado Tocino \& M. C. Romeo Mateo (Eds.), Heroinas y patriotas. Mujeres de 1808 (pp.193-268). Madrid: Catedra.

Veenendaal, W.P. (2015). The Dutch Caribbean municipalities in comparative perspective. Island Studies Journal, 10(1), 15-30.

Vergé-Franceschi, M. (2005). Paoli, une corse des Lumièrs. Paris: Fayard.

Vézina, V. (2014). The role of the political system in shaping island nationalism: a case-study examination of Puerto Rico and Newfoundland. Island Studies Journal, 9(1), 103-122.

Warrington, E. \& Milne, D. (2007). Island Governance. in G. Baldacchino (Ed.). A World of Islands. An Island Studies Reader (pp. 379-427). Charlottetown: Institute of Islands Studies.

Waterston, E. (1998). The iconography of Islands: Margaret Atwood and L.M. Montgomery. In L. Brinklow, F. Ledwell \& J. Ledwell (Eds.). Message in a Bottle: The Literature of Small Islands (pp. 265-276). Charlottetown: Institute of Island Studies.

Wilson, S. (1988), Feuding, Conflict and Banditry in $19^{\text {th }}$ Century Corsica. Cambridge: Cambridge University Press. https://doi.org/10.1017/CBO9780511523557 